\title{
Kompetensi Emosi dan Kepemimpinan Transformasional di Sekolah Berkesan dan Sekolah Kurang Berkesan
}

\author{
YAHYA DON ${ }^{1}$ \\ YAAKOB DAUD ${ }^{2}$ \\ College of Arts and Sciences \\ Universiti Utara Malaysia \\ dr.yahya@uum.edu.my ${ }^{l}$ \\ yaakob@uum.edu.my²
}

\begin{abstract}
ABSTRAK
Kepemimpinan merupakan proses hubungan interpersonal yang dinamik, meluas merangkumi aspek-aspek kognitif, kompetensi emosi dan beroperasi dalam konteks sosial. Kajian ini bertujuan meneliti tahap kompetensi emosi pemimpin dan kepemimpinan transformasional di sekolah berkesan dan sekolah kurang berkesan. Seramai 485 pemimpin secara random telah terpilih dari sekolah tersebut dengan mengunakan Emotional Competencies Inventory (ECI-2) dan Multifactor Leadership Questionnaire (MLQ5x). Dapatan menunjukan terdapat perbezaan yang signifikan dalam tahap kompetensi emosi dan kepemimpinan transformasional di sekolah berkesan dan sekolah kurang berkesan. Perbezaan ini memberi pengaruh yang sangat besar ke atas kejayaan dan imej terhadap kepimpinan sekolah. Oleh itu, usaha-usaha perlu dilakukan untuk meningkatkan tahap kompetensi emosi dan kepemimpinan transformasional pemimpin di sekolah kurang berkesan dalam usaha untuk meningkatkan bilangan sekolah-sekolah berkesan.
\end{abstract}

\section{ABSTRACT}

Purpose - This paper is to identify leader emotional competency level and transformational leadership in effective and ineffective school. Total of 485 leaders randomly selected from school by using Emotional Competencies Inventory (ECI-2) and Multifactor Leadership Questionnaire (MLQ5x). Findings shows there is significant difference of emotional competencies levels and 
transformational leadership in effective and ineffective school. The differences gave a big influences toward success and image of school leadership. In order to improving school effectiveness, strong effort has to be done to enhance emotional competencies and transformational leadership level towards school leaders in ineffective school.

Method - Method of data collection were employed in this study, namely survey method. In the survey method, questionnaire was utilizes that is Emotional Competence Inventory (ECI-2) and Multifactor Leadership Questionnaire (MLQ5x), and returned by 485 respondents (233 respondents from effective school and 251 respondent from less effective school) from Perlis, Kedah, Pulau Pinang and Perak in northern part of Peninsular Malaysia.

Findings - The result revealed that was a significant relationship between school leadership emotional competencies and transformational leadership in effective school and less effective school. The study indicates significant difference in the school leader emotional competence and the transformational leadership between effective school and less effective school. The hypothesis for differences in term of age and gender at effective and less effective school was supported. This study also found that the dimension of the adaptability and influence played significant role as an influence to the process of transformational leadership in the effective school.

Significance - The paper explores extensively the possible implications of the study and addresses these to school and school leadership, teachers and ministry of education in Malaysia.

Keywords: Schools leadership, emotional intelligence, and learning communities in schools effective.

\section{PENGENALAN}

Dalam era pascamodernisasi, kecerdasan emosi pemimpin didapati mempunyai hubungan yang signifikan dengan keberkesanan sekolah dan perkembangan pendidikan yang semakin kompleks. Kecerdasan emosi didapati merupakan elemen penting menyumbang kepada wujudnya hubungan yang efektif antara pemimpin dengan 
subordinat dalam sesebuah organisasi dan mempengaruhi pemusatan dalam proses hubungan antara pemimpin dengan subordinat. Situasi ini secara tidak langsung akan mewujudkan proses pendemokrasian, kolaborasi dan proses pengagihan dalam kepemimpinan sesuatu organisasi. Sehubungan itu, perlunya suatu agenda dalam kepemimpinan pendidikan ke arah mewujudkan suatu ethos atau iklim yang bersesuaian dalam sesebuah organisasi sekolah.

Pemimpin yang mempunyai emosi dan sikap yang positif banyak memberi sumbangan kepada kecemerlangan organisasi, lebih mudah untuk berinteraksi, kurang agresif, lebih senang membantu orang lain, membuat komen yang membina dan mengambil tindakan yang dapat meningkatkan kepuasan kerja kakitangan dalam organisasi. Situasi ini dapat dilihat melalui dapatan kajian oleh George dan Bettenhausen (1990), yang memperlihatkan pemimpin yang mempunyai emosi yang positif dapat bekerja dalam suasana yang positif akan dapat membantu dalam mempertingkatkan kualiti perkhidmatan stafnya. Keadaan ini seterusnya akan dapat mewujudkan organisasi yang lebih berkesan jika dibandingkan dengan pemimpin yang kurang berpengalaman dalam mengurus emosi. Dalam hal ini, kepemimpinan pendidikan perlu memahami sifat, keperluan dan emosi dirinya serta guru-guru di sekolahnya. Hal ini kerana kepemimpinan pendidikan di sekolah hari ini perlu berhubung dengan pelbagai sifat manusia yang sukar dipelajari malah sering pula dicabar oleh perubahan tanggungjawab, harapan, serta hala tuju pendidikan dalam sesebuah negara (Forsyth, 2000).

\section{KECERDASAN EMOSI PEMIMPIN DAN KEBERKESANAN ORGANISASI}

Menurut Goleman (1998), hubungan antara kecerdasan emosi pemimpin dengan keberkesanan organisasi merupakan hubungan yang signifikan dan penting. Hal ini disokong oleh Weisinger (1998) yang menyatakan bahawa kemahiran analisis, kesetiaan terhadap organisasi dan kompetensi bukanlah sesuatu yang berpanjangan sebagai asas kejayaan seseorang itu dalam pekerjaan. Menurut Weisinger (1998) lagi, mereka yang berjaya menjadi pemimpin korporat dalam masa yang singkat adalah terdiri daripada mereka yang telah berjaya menunjukkan kecerdasan emosi yang tinggi dan dapat meningkatkan kemajuan dalam sesebuah organisasi. Hal yang sama juga ditunjukkan oleh Feldman (1999) yang mendapati 
pemimpin yang mempunyai kecerdasan emosi, mengaplikasikannya dan mempunyai kemahiran sosial yang positif dapat mempengaruhi usaha-usaha rakan dan subordinat dalam meningkatkan kemajuan organisasi.

Noyes (2002), mencadangkan kecerdasan emosi pemimpin sebagai jangkaan utama ke atas keberkesanan organisasi dalam membina hubungan berterusan dengan pengguna, dan pembekal. Chastukhina (2002) menunjukkan pemimpin yang mempunyai kecerdasan emosi yang tinggi lebih empati dan bermotivasi serta Tebih memahami kekurangan atau kelemahan serta berkebolehan mengawal emosinya. Menurut Feldman (1999) identiti kemahiran kecerdasan emosi pemimpin termasuklah memahami emosi dirinya dan orang lain yang merupakan asas penting keberkesanan dalam sesebuah organisasi. Dyer (2001) juga menyatakan perkara yang sama iaitu asas organisasi yang berkesan bergantung kepada kepemimpinan yang menguasasi kemahiran dalam hubungan manusia, dan memahami bila dan kepada siapa sesuatu tindakan atau tugas itu perlu dilaksanakan. George (2000) menyatakan pemimpin yang mempunyai kecerdasan emosi yang tinggi mungkin boleh menyerap kepada organisasinya semangat, kecekalan dan sikap optimis dalam usaha untuk membina kepercayaan dan kerjasama melalui hubungannya dengan subordinatnya. Bass (1990) melihat kemahiran berhubungan dengan orang lain seperti empati, memahami hati nuraini, lebih berwaspada dan berkemampuan untuk memberi maklum balas sebagai kemahiran kepemimpinan yang penting.

Kajian oleh Barling, Slater dan Kelloway (2000) melihat kompetensi emosi pemimpin dan kepemimpinan transformasional, mendapati kecerdasan emosi pemimpin memberi impak terhadap tiga aspek utama dalam kepemimpinan transformasional iaitu karismatik, mencetus motivasi dan pertimbangan secara individu. Manakala kecerdasan emosi pemimpin tidak memberi sebarang impak ke atas pengurusan pengecualian sama ada aktif atau pasif serta kepemimpinan laissez-faire. Walau bagaimanapun kajian tentang kecerdasan emosi dalam kalangan pemimpin pendidikan agak jarang, apabila terdapat hanya dua kajian untuk mengenal pasti kemahiran kecerdasan emosi dalam kepemimpinan pendidikan. Lees dan Barnard (1999) mengesahkan apabila seseorang pengetua mempamerkan kemampuannya dalam kecerdasan emosi tertentu, kepuasan kerja guru dan pencapaian pelajar juga akan meningkat. Maka berasaskan pendirian ini, penelitian peringkat awal mengenai 
keberkesanan organisasi cuba untuk mengaitkan hubungan tingkah laku kepemimpinan dengan kepentingan aspek emosi pemimpin (Bass, 1985; Tichy \& Devanna, 1990; Kanungo, 1998). Penelitian oleh Burns (1978) mendapati kepemimpinan transformasional merupakan proses pemimpin dan subordinat berusaha untuk mencapai tahap yang tertinggi dalam aspek moral dan motivasi. Secara umumnya proses kepemimpinan ini menekankan kepada aspek emosi dan identifikasi pemimpin yang merupakan asas utama mempengaruhi subordinat dalam sesuatu organisasi (Yukl, 2002).

\section{KEPEMIMPINAN TRANSFORMASIONAL DAN SEKOLAH BERKESAN}

Kepemimpinan transformasional merupakan tingkah laku kepemimpinan yang lebih berkesan ke arah mewujudkan sekolah berkesan dalam sistem pendidikan masa kini (Button, 2003). Kebanyakan penyelidik telah mencadangkan keperluan perubahan kepada gaya kepemimpinan transformasional, kerana ianya merupakan jalan yang terbaik dalam usaha untuk melakukan reformasi di sekolah dan penyusunan semula sistem pendidikan (Bass \& Avalio, 1994).

Kepemimpinan transformasional merupakan jalan terbaik untuk melakukan perubahan terhadap persekitaran sekolah. Hal ini adalah kerana kepemimpinan mempunyai pengetahuan dan kemahiran untuk mengadaptasikan perubahan situasi secara berterusan (Chou Lin, 1999). Kepemimpinan transformasional mempunyai beberapa kriteria seperti lebih fleksibel, minda yang terbuka, sensitif terhadap keperluan individu, mendorong penglibatan yang aktif dan secara berkumpulan, perkongsian dalam membuat keputusan, dan mempunyai sikap toleransi yang tinggi (Stone, 1992). Dalam keadaan yang praktikal, merujuk kepada Leithwood (1993), strategi kepemimpinan transformasional dapat membantu staf untuk membina dan mengekalkan kolaborasi, budaya sekolah yang positif dan lebih profesional, mendorong kepada pembangunan dan pengkayaan minda guru dan membantu guru-guru untuk menyelesaikan masalah secara kreatif, inovatif dan efektif. Perkongsian dalam membuat keputusan, bermakna mengagihkan kuasa dan tindakan kepemimpinan seperti ini merupakan kecenderungan yang terdapat dalam kebanyakan organisasi pendidikan kini (Blasé \& Blasé, 1994). 
Di sekolah, guru-guru akan dilibatkan dalam penyelesaian masalah dan membuat keputusan. Hal ini secara tidak langsung menunjukkan bahawa peranan pemimpin sekolah yang mengamalkan kepemimpinan transformasional dalam pengurusan sekolah bukanlah sesuatu yang bersifat dominan seperti dalam sistem tradisi (Herman, 1991). Kebanyakan pemimpin pendidikan belajar untuk melakukan perubahan melalui proses pembelajaran secara individu dan bersifat kolaboratif (Haskin, 1995). Keputusan kajian menunjukkan ianya lebih positif daripada negatif. Praktis mengagihkan tugas dan kuasa kepada guru-guru oleh kepemimpinan transformasional sebenarnya tidak memberi kesan atau menyebabkan kepemimpinan sekolah kehilangan kuasa, malah dalam masa yang sama mereka akan lebih dihormati dan sentiasa mendapat kerjasama daripada guru-guru (Chou Lin, 1999). Secara tidak langsung, hal yang demikian dapat meningkatkan kepuasan kerja guru dan seterusnya dapat menjadikan sesebuah sekolah itu lebih berkesan (Blasé, Blasé, Anderson \& Dungan, 1995).

Bennis dan Nanus (1985) menyatakan seseorang yang melakukan perkara yang betul adalah pengurus tetapi seseorang yang membetulkan sesuatu perkara adalah pemimpin. Justeru pemimpin yang berkesan adalah diharapkan untuk mengubah sesuatu keadaan daripada keadaan yang tidak memuaskan kepada keadaan yang lebih stabil, daripada keadaan yang tidak tersusun kepada lebih sistematik dan daripada kekecewaan kepada penuh harapan. Hal ini merupakan peranan kepemimpinan transformasional dalam membentuk visi, inisiatif, motivasi, mobiliti dan menyelesaikan kerja secara efektif seterusnya menjelmakan visi kepada realiti (Chou Lin, 1999). Kepemimpinan transformasional juga merupakan kepemimpinan yang mempunyai visi (Goldring \& Rallis, 1993). Tanpa visi seseorang pemimpin tidak akan mempunyai panduan yang jelas hala tuju sesebuah sekolah harus dibawa dan hanya akan mengekalkan status quo tanpa mobiliti. Kepemimpinan yang berkesan akan membina strateginya untuk berurusan dengan situsasi yang berbeza dan dengan penuh kreativiti (Sergiovanni, 1996).

Menurut Chou Lin (1999) kepemimpinan transformasional merupakan aspek penting kepada pemimpin pendidikan kini dalam usaha untuk melakukan perubahan dan menyelesaikan krisis di sekolah. Kepemimpinan transformasional berkemampuan mengesan dan menyediakan jalan keluar kepada pelbagai masalah yang sedang berlaku. Tingkah laku pemimpin sekolah perlu berubah daripada satu situasi kepada situasi yang lain untuk mengoptimumkan 
tindakan dan ianya merupakan prasyarat kepada trait kepemimpinan transformasional. Kajian oleh Lashway (1997) mencadangkan beberapa garis panduan sesuai untuk dikuti oleh kepemimpinan sekolah antaranya ialah; 1 . menyesuaikan strategi dengan situasi; 2. menyeimbangkan antara proses dengan hasil dan; 3. membina tingkah laku kepemimpinan yang seimbang. Strategi pengurusan yang dibina melalui kepemimpinan transformasional merupakan jalan terbaik untuk mewujudkan sekolah yang berkesan.

Walaupun terdapat beberapa kajian yang signifikan tentang kepemimpinan dan emosi (Stogdill, 1974; Yukl, 2002; Yukl \& VanFleet, 1992), tetapi kajian ini kurang mendalam dan spesifik terutamanya dalam kepemimpinan sekolah. Kekurangan kajian empirikal untuk menyokong pemboleh ubah tersebut menyebabkan perbincangan mengenai kualitinya adalah sukar. Saban tahun terdapat pelbagai pendekatan teoritikal dicadangkan dan diuji untuk melihat hubungan pemboleh ubah yang lebih spesifik dengan sekolah berkesan, namun tidak dapat menunjukkan suatu entiti yang terpisah. Kajian lepas gagal menunjukkan kemahiran yang dapat berdiri dengan sendirinya untuk melihat pengaruh kepemimpinan dan sekolah berkesan. Maka berdasarkan kepentingan tersebutlah, kaedah kompetensi emosi pemimpin memberi kesan kepada kepemimpinan transformasional di sekolah berkesan dan sekolah kurang berkesan akan diteliti dalam kajian ini. Kaedah ini dijalankan dengan menghipotesiskan bahawa kompetensi emosi pemimpin mempunyai pengaruh terhadap kepemimpinan transformasional jika bersesuaian dengan situasi yang didefinisikan berasaskan sekolah berkesan dan sekolah kurang berkesan.

\section{KAEDAH KAJIAN}

Kajian ini bertujuan memperjelas perbezaan kompetensi emosi pemimpin di sekolah berkesan dan sekolah kurang berkesan. Kajian ini lebih berbentuk deskriptif-korelasi yang melibatkan pengumpulan data bagi tujuan menyediakan ciri-ciri kompetensi emosi pemimpin sekolah dan hubungannya dengan variabel yang lain (Johnson \& Christensen, 2005). Pendekatan yang biasa digunakan untuk mengumpul maklumat dalam kajian deskriptif ialah kaedah tinjauan keratan rentas (cross-sectional survey) berdasarkan soal selidik yang dijawab oleh responden (Johnson \& Christensen, 2005). 
Populasi bagi kajian ini ialah sekolah-sekolah berkesan dan sekolah kurang berkesan di zon utara, semenanjung Malaysia iaitu negeri Perlis, Kedah, Pulau Pinang dan Perak. Populasi kajian ini iaitu sekolah berkesan berjumlah 44 buah dengan pecahan seperti berikut; tujuh buah sekolah di Perlis, sebelas buah sekolah di Kedah, 18 buah sekolah di Pulau Pinang dan lapan buah sekolah di Perak. Manakala sekolah kurang berkesan berjumlah 140 buah sekolah dengan pecahan iaitu, 16 buah sekolah di Perlis, 17 buah sekolah di Kedah, 24 buah sekolah di negeri Pulau Pinang dan 83 buah sekolah bagi negeri Perak. Jumlah sekolah rendah yang dipilih sebagai sampel kajian ini ialah 40 buah sekolah berkesan dan 40 buah sekolah kurang berkesan. Kriteria lokasi pemilihan sekolah sama ada bandar atau luar bandar tidak diambil kira dalam kajian ini kerana ianya didapati tidak mempengaruhi aspek kompetensi emosi pemimpin (Boyatzis, 2001; Goleman, 2000). Bagi kajian ini, kaedah persampelan rambang berstrata dilakukan mengikut katogeri sekolah iaitu sekolah berkesan dan sekolah kurang berkesan. Kajian yang telah dijalankan secara keratan rentas (cross-sectional survey) ini melibatkan 485 orang pemimpin di sekolah berkesan dan sekolah kurang berkesan.

Soal selidik yang digunakan dalam penelitian ini ialah Emotional Competencies Inventory (ECI-2) (Boyatzis, 2001) - dan Multifactor Leadership Questionnaire (MLQ5x) (Bass \& - Avalio, 2000). Soal selidik ECI-2 membahagikan kompetensi emosi pemimpin kepada empat kelompok iaitu (1) kesedaran diri yang berkaitan kesedaran emosi diri, penilaian diri yang tepat, dan keyakinan diri; (2) pengurusan diri merangkumi pengawalan emosi kendiri, ketelusan, kebolehsuaian, sikap optimis, orientasi pencapaian, dan inisiatif; (3) kesedaran sosial merangkumi, empati, orientasi khidmat, dan kesedaran organisasi; dan Pengurusan perhubungan merangkumi membangunkan orang lain, kepemimpinan berinspirasi, pemangkin perubahan, pengaruh, pengurusan konflik, dan kerjasama berkumpulan.

Kepemimpinan diukur menggunakan skala Multifactor Leadership Questionnaire (MLQ5x) (Bass \& Avolio, 2000). Skala MLQ5x menggunakan empat item soalan bagi mengukur lapan subskala komponen kepemimpinan dan satu komponen yang mengukur atribut. Tingkah laku kepemimpinan Transformasional mengandungi empat komponen yang diukur melalui MLQ5x (Bass \& Avalio, 2000) iaitu; (1) merangsang intelektual; (2) pertimbangan 
individu; (3) karismatik (atribut dan tingkah laku); dan (4) mencetus motivasi. Tingkah laku kepemimpinan Transaksi mengandungi dua faktor yang diukur melalui MLQ5x (Bass \& Avalio, 2000) iaitu (a) ganjaran luar jangka dan (b) pengurusan pengecualian (pasif dan aktif). Seterusnya tingkah laku kepemimpinan Laissez-Faire menunjukkan tiada unsur-unsur dalam memimpin subordinat (Bass \& Avalio, 1993). Situasi ini memperlihat bahawa kepemimpinan tidak menonjol dan mengelak daripada melakukan intervensi. Keputusan sentiasa dilewatkan; maklum balas, ganjaran dan tiada penglibatan; dan mereka tidak melakukan sebarang usaha untuk memotivasikan subordinat atau menghargai dan memenuhi keperluan mereka (Bass \& Avolio, 1993).

\section{Jadual 1}

Konstruk, Faktor dan Skala MLQ5x

$\begin{array}{lcc}\text { Konstruk } & \text { Komponen } & \text { Skala } \\ \text { Kepemimpinan } & & \text { (Bilangan Item) }\end{array}$

\begin{tabular}{|c|c|c|}
\hline \multirow{5}{*}{$\begin{array}{l}\text { Kepemimpinan } \\
\text { Transformasional }\end{array}$} & Merangsang Intelektual & Merangsang Intelektual (4) \\
\hline & Pertimbangan Individu & Pertimbangan Individu (4) \\
\hline & Karismatik & Karismatik (tingkah laku) (4) \\
\hline & & Karismatik (atribut) (4) \\
\hline & Mencetus Motivasi & Mencetus Motivasi (4) \\
\hline \multirow{3}{*}{$\begin{array}{l}\text { Kepemimpinan } \\
\text { Transaksi }\end{array}$} & Ganjaran Luar Jangka & Ganjaran Luar Jangka (4) \\
\hline & Pengurusan Pengecualian & $\begin{array}{l}\text { Pengurusan Pengecualian } \\
\text { (aktif) (4) }\end{array}$ \\
\hline & & $\begin{array}{l}\text { Pengurusan Pengecualian } \\
\text { (Pasif) (4) }\end{array}$ \\
\hline $\begin{array}{l}\text { Kepemimpinan } \\
\text { Laissez-Faire }\end{array}$ & Laissez-Faire & Laissez-Faire (4) \\
\hline
\end{tabular}

Sumber. Avolio, Bass, \& Jung (1995); Bass \& Avolio, (2000)

Kebolehpercayaan item-item yang digunakan untuk mengukur konstruk kompetensi emosi pemimpin dan kepemimpinan transformasional dianalisis dengan menggunakan Cronbach Alpha $(\alpha)$ berdasarkan bilangan sampel sebenar $(\mathrm{N}=485)$. 
Jadual 2

\section{Analisis Kebolehpercayaan Instrumen}

\section{Konstruk}

Kompetensi Emosi

Kesedaran Diri

Kesedaran Sosial

Pengurusan Diri

Pengurusan Perhubungan

Kepemimpinan Transformasional

Kepemimpinan Transaksi

Kepemimpinan Laissez-Faire
Bilangan item

72

0.94

12

0.80

12

0.72

24

0.88

24

0.82

20

0.92

12

0.85

04

0.74

Dalam kajian ini, analisis kebolehpercayaan merujuk kepada Emotional Competence Inventory (ECI-2) (Boyatzis, 2001) dan Multifactor Leadership Questionnaire (MLQ5x) (Bass \& Avolio, 2000). Merujuk kepada Jadual 2, keseluruhan kelompok kompetensi emosi berdasarkan pengukuran soal selidik ECI-2 mempunyai nilai alpha yang tinggi iaitu $\alpha=.94$. Nilai alpha bagi kelompokkelompok berkenaan ialah kesedaran diri $(\alpha=.69)$, pengurusan diri $(\alpha=.88)$, kesedaran sosial $(\alpha=.79)$ dan pengurusan perhubungan $(\alpha=.78)$. Nilai alpha ini secara keseluruhan memuaskan dan boleh diterima guna dalam konteks penyelidikan pendidikan (Gorard, 2001; Johnson \& Christenen, 2004).

Bagi mengukur kepemimpinan berdasarkan instrumen MLQ5x (Bass \& Avolio, 2000), secara keseluruhan dimensi tingkah laku kepemimpinan Transformasional menunjukkan nilai yang tinggi iaitu $\alpha=.92$. Bagi tingkah laku kepemimpinan Transaksi ialah $\alpha=.85$. Selepas analisis faktor diambil kira Alpha Cronbach bagi subskala kompetensi emosi pemimpin dan kepemimpinan juga menunjukkan nilai yang tinggi. Analisis kebolehpercayaan instrumen ini menunjukkan tidak ada perubahan item bagi ECI-2 dan MLQ5x kerana Cronbach's Alpha if item deleted menunjukkan kurang daripada nilai Cronbach's Alpha bagi keseluruhan item. 


\section{DAPATAN KAJIAN}

\section{Kompetensi Emosi Pemimpin di Sekolah Berkesan dan Sekolah Kurang Berkesan}

Terdapat tiga pemboleh ubah demografi yang digunakan dalam kajian ini iaitu umur, jantina dan pengalaman pentadbiran. Bagi menguji tahap kompetensi emosi berdasarkan umur dan pengalaman pentadbiran, kaedah MANOVA (Multivariate Analysis of Variance) telah digunakan. Hal ini kerana wujudnya korelasi antara faktorfaktor dalam konstruk kompetensi emosi pemimpin apabila diuji dengan Bartlett's Test of Sphevicity yang telah memberi nilai sebanyak 18621.91; df = 2556; $\mathrm{p}<0.05$. Keputusan ini meyakinkan kepada penyelidik bahawa analisis MANOVA sesuai digunakan. Bagi mengenal pasti perbezaan multivariate merentasi kumpulan pula, kriteria Pillai's trace dan Roy's Largest Root seperti yang disarankan oleh Coakes dan Steed, (2003) digunakan dalam kajian ini.

\section{Perbezaan Kompetensi Emosi Pemimpin Mengikut Umur}

Sebanyak empat kumpulan umur responden telah digunakan dalam analisis MANOVA iaitu kumpulan pemimpin sekolah berumur 20 hingga 29 tahun; 30 hingga 39 tahun; 40 hingga 49 tahun dan 50 tahun dan ke atas. Manakala analisis MANOVA perlu dilakukan dalam dua peringkat iaitu pada peringkat pertama kompetensi emosi pemimpin secara keseluruhan dan subskala kompetensi dijadikan pemboleh ubah bersandar. Pada peringkat kedua pula semua subskala kompetensi emosi pemimpin dijadikan pemboleh ubah bersandar.

Hasil ujian Multivariate menunjukkan terdapat perbezaan secara signifikan antara kumpulan umur terhadap kompetensi emosi pemimpin, apabila merujuk kepada nilai Pillai's trace adalah sebanyak $0.171(\mathrm{~F}=7.237, \mathrm{p}<0.05)$ dan Roy's Largest Root pula memperoleh nilai sebanyak $0.179(\mathrm{~F}=21.462 ; \mathrm{p}<0.05)$. Secara amnya, ujian Multivariate seperti yang dipaparkan dalam Jadual 3, menunjukkan bahawa terdapat perbezaan dari segi kompetensi emosi pemimpin secara keseluruhan $(\mathrm{F}=23.45$; $\mathrm{p}<0.05)$; kelompok kesedaran diri $(\mathrm{F}=20.40 ; \mathrm{p}<0.05)$; kelompok kesedaran sosial $(\mathrm{F}$ $=14.20 ; \mathrm{p}<0.05)$; kelompok pengurusan diri $(\mathrm{F}=16.35 ; \mathrm{p}<0.05)$; dan kelompok pengurusan perhubungan $(\mathrm{F}=26.13$; $\mathrm{p}<0.05)$. 
Jadual 3

Analisis MANOVA bagi Perbezaan Kompetensi Emosi Pemimpin Berdasarkan Umur di Sekolah Berkesan dan Sekolah Kurang Berkesan

\begin{tabular}{|c|c|c|c|c|c|}
\hline $\begin{array}{c}\text { Kelompok } \\
\text { Kompetensi } \\
\text { Emosi Pemimpin }\end{array}$ & $\begin{array}{c}20-29 \mathrm{Th} . \\
(\mathrm{n}=54) \\
\operatorname{Min}(\mathrm{S.P})\end{array}$ & $\begin{array}{l}\text { 30- } 39 \text { Th. } \\
(n=124) \\
\text { Min (S.P) }\end{array}$ & $\begin{array}{l}\text { 40- } 49 \text { Th. } \\
(n=163) \\
\operatorname{Min}(S . P)\end{array}$ & $\begin{array}{c}50 \text { Th. dan } \\
\text { ke atas } \\
(n=144) \\
\text { Min (S.P) }\end{array}$ & Nilai $\mathbf{F}$ \\
\hline Kompetensi Emosi & $3.53(0.24)$ & $3.70(0.37)$ & $3.85(0.35)$ & $3.94(0.35)$ & $23.45 * *$ \\
\hline Kesedaran Diri & $3.57(0.22)$ & $3.75(0.31)$ & $3.88(0.32)$ & $3.91(0.32)$ & $20.40 * *$ \\
\hline Kesedaran Sosial & $3.50(0.34)$ & $3.64(0.53)$ & $3.80(0.51)$ & $3.94(0.49)$ & $14.20 * *$ \\
\hline Pengurusan Diri & $3.55(0.38)$ & $3.71(0.43)$ & $3.86(0.40)$ & $3.94(0.38)$ & $16.35 * *$ \\
\hline $\begin{array}{l}\text { Pengurusan } \\
\text { Perhubungan }\end{array}$ & $3.51(0.31)$ & $3.68(0.40)$ & $3.86(0.39)$ & $3.98(0.38)$ & $26.13 * *$ \\
\hline
\end{tabular}

$* * \mathrm{p}<0.01 ; * \mathrm{p}<0.05$

Dapatan ini menjelaskan bahawa semakin tinggi umur seseorang responden maka tahap kompetensi emosi pemimpin juga akan turut meningkat. Hal ini jelas apabila dirujuk kepada pertambahan skor min berdasarkan umur. Justeru, keputusan ini menunjukkan tidak terdapat perbezaan yang signifikan dan positif dalam kompetensi emosi pemimpin berdasarkan pemboleh ubah umur pemimpin di sekolah berkesan dan sekolah kurang berkesan; adalah ditolak.

Analisis lanjutan turut dilakukan bagi mengenal pasti perbezaan subskala-subskala kompetensi emosi pemimpin berdasarkan umur responden (Jadual 4). Hasil analisis MANOVA mendapati terdapat perbezaan skor min subskala kompetensi emosi pemimpin secara signifikan jika dirujuk kepada nilai Pillai trace yang diperoleh sebanyak 0.325 ( $\mathrm{F}=3.148 ; \mathrm{p}<0.05)$ dan Roy's Largest Root sebanyak $0.264(\mathrm{~F}=6.827 ; \mathrm{p}<0.05)$. Perbezaan yang signifikan berlaku dalam semua subskala kompetensi emosi pemimpin iaitu subskala kesedaran emosi diri $(\mathrm{F}=14.65 ; \mathrm{p}<0.05)$; ketepatan penilaian kendiri $(\mathrm{F}=4.09 ; \mathrm{p}<0.05)$; keyakinan diri $(\mathrm{F}=23.49 ; \mathrm{p}<$ 0.05); empati $(\mathrm{F}=12.21 ; \mathrm{p}<0.05)$; orientasi khidmat $(\mathrm{F}=3.27 ; \mathrm{p}<$ $0.05)$; kesedaran organisasi $(\mathrm{F}=19.34 ; \mathrm{p}<0.01)$; pengawalan emosi $\operatorname{diri}(\mathrm{F}=17.14 ; \mathrm{p}<0.01)$; orientasi pencapaian $(\mathrm{F}=7.79 ; \mathrm{p}<0.01)$; sikap optimis $(\mathrm{F}=12.07 ; \mathrm{p}<0.01)$; ketelusan $(\mathrm{F}=17.89 ; \mathrm{p}<0.01)$; kebolehsuaian $(\mathrm{F}=12.83 ; \mathrm{p}<0.05)$; membangunkan orang lain $(\mathrm{F}$ 
$=19.64 ; \mathrm{p}<0.05) ;$ kepemimpinan berinspirasi $(\mathrm{F}=18.56 ; \mathrm{p}<0.05)$; pemangkin perubahan $(\mathrm{F}=17.95 ; \mathrm{p}<0.05)$; pengurusan konflik $(\mathrm{F}$ $=8.15 ; \mathrm{p}<0.05)$; pengaruh $(\mathrm{F}=6.96 ; \mathrm{p}<0.05)$; kerja kumpulan kolaborasi $(\mathrm{F}=16.81 ; \mathrm{p}<0.05)$ kecuali bagi subskala inisiatif $(\mathrm{F}$ $=2.34 ; \mathrm{p}>0.05)$.

Dalam hal ini, sekali lagi dapat diperhatikan bahawa skor min subskala kompetensi emosi pemimpin semakin bertambah apabila semakin meningkat umur seseorang itu. Kompetensi emosi pemimpin bertambah apabila umurnya semakin meningkat pemimpin dalam kedua-dua katogeri sekolah tersebut

Jadual 4

Analisis MANOVA bagi Perbezaan Subskala Kompetensi Emosi Pemimpin Berdasarkan Umur di Sekolah Berkesan dan Sekolah Kurang Berkesan

\begin{tabular}{|c|c|c|c|c|c|}
\hline $\begin{array}{l}\text { Subskala } \\
\text { Kompetensi Emosi } \\
\text { Pemimpin }\end{array}$ & $\begin{array}{c}20-29 \mathrm{Th} . \\
(\mathrm{n}=54) \\
\operatorname{Min}(\mathrm{S} . \mathrm{P})\end{array}$ & $\begin{array}{l}\text { 30- } 39 \text { Th. } \\
(n=124) \\
\text { Min (S.P) }\end{array}$ & $\begin{array}{l}\text { 40- } 49 \mathrm{Th} . \\
(\mathrm{n}=163) \\
\operatorname{Min}(\mathrm{S} . \mathrm{P})\end{array}$ & $\begin{array}{l}50 \text { Th. dan } \\
\text { ke atas } \\
(n=144) \\
\text { Min (S.P) }\end{array}$ & Nilai $\mathbf{F}$ \\
\hline Kesedaran Emosi Diri & $3.64(0.32)$ & $3.81(0.45)$ & $3.98(0.43)$ & $4.03(0.45)$ & $14.65 * *$ \\
\hline $\begin{array}{l}\text { Ketepatan Penilaian } \\
\text { Kendiri }\end{array}$ & $3.27(0.30)$ & $3.40(0.29)$ & $3.45(0.36)$ & $3.38(0.33)$ & $4.09 * *$ \\
\hline Keyakinan Diri & $3.77(0.33)$ & $4.05(0.48)$ & $4.21(0.40)$ & $4.31(0.45)$ & $23.49 * *$ \\
\hline Empati & $3.79(0.47)$ & $3.88(0.53)$ & $4.11(0.51)$ & $4.16(0.46)$ & $12.21 * *$ \\
\hline Orientasi Khidmat & $3.24(0.62)$ & $3.34(0.74)$ & $3.48(0.73)$ & $3.55(0.76)$ & $3.27 *$ \\
\hline Kesedaran Organisasi & $3.47(0.48)$ & $3.70(0.65)$ & $3.81(0.67)$ & $4.13(0.53)$ & $19.34 * *$ \\
\hline $\begin{array}{l}\text { Pengawalan Emosi } \\
\text { Diri }\end{array}$ & $3.45(0.34)$ & $3.69(0.46)$ & $3.80(0.48)$ & $3.94(0.44)$ & $17.14 * *$ \\
\hline Orientasi Pencapaian & $3.68(0.51)$ & $3.78(0.55)$ & $3.94(0.54)$ & $4.03(0.55)$ & $7.79 * *$ \\
\hline Sikap Optimis & $3.81(0.46)$ & $3.99(0.58)$ & $4.17(0.50)$ & $4.24(0.51)$ & $12.07 * *$ \\
\hline Ketelusan & $3.79(0.41)$ & $3.96(0.51)$ & $4.07(0.45)$ & $4.28(0.42)$ & $17.89 * *$ \\
\hline Kebolehsuaian & $3.54(0.58)$ & $3.69(0.46)$ & $3.93(0.54)$ & $3.94(0.47)$ & $12.83 * *$ \\
\hline Inisiatif & $3.02(0.62)$ & $3.10(0.68)$ & $3.25(0.64)$ & $3.22(0.62)$ & 2.34 \\
\hline $\begin{array}{l}\text { Membangunkan } \\
\text { Orang Lain }\end{array}$ & $3.55(0.54)$ & $3.64(0.52)$ & $3.90(0.55)$ & $4.05(0.47)$ & $19.64 * *$ \\
\hline
\end{tabular}




\begin{tabular}{|c|c|c|c|c|c|}
\hline $\begin{array}{l}\text { Subskala } \\
\text { Kompetensi Emosi } \\
\text { Pemimpin }\end{array}$ & $\begin{array}{c}20-29 \text { Th. } \\
(n=54) \\
\text { Min (S.P) }\end{array}$ & $\begin{array}{l}\text { 30- } 39 \text { Th. } \\
(n=124) \\
\operatorname{Min}(S . P)\end{array}$ & $\begin{array}{l}40-49 \text { Th. } \\
(n=163) \\
\text { Min (S.P) }\end{array}$ & $\begin{array}{l}50 \text { Th. dan } \\
\text { ke atas } \\
(n=144) \\
\text { Min }(\text { S.P })\end{array}$ & Nilai F \\
\hline $\begin{array}{l}\text { Kepemimpinan } \\
\text { Berinspirasi }\end{array}$ & $3.59(0.57)$ & $3.86(0.62)$ & $4.06(0.53)$ & $4.19(0.52)$ & $18.56 * *$ \\
\hline Pemangkin Perubahan & $3.37(0.54)$ & $3.55(0.58)$ & $3.96(0.60)$ & $3.95(0.54)$ & $17.95 * *$ \\
\hline Pengurusan Konflik & $3.40(0.44)$ & $3.58(0.43)$ & $3.67(0.45)$ & $3.74(0.47)$ & $8.15^{* *}$ \\
\hline Pengaruh & $3.31(0.57)$ & $3.43(0.68)$ & $3.63(0.62)$ & $3.67(0.57)$ & $6.96 * *$ \\
\hline $\begin{array}{l}\text { Kerja Kumpulan- } \\
\text { Kolaborasi }\end{array}$ & $3.81(0.37)$ & $4.03(0.51)$ & $4.21(0.44)$ & $4.27(0.46)$ & $16.81 * *$ \\
\hline
\end{tabular}

$* * \mathrm{p}<0.01 ; * \mathrm{p}<0.05$

Perbezaan Kompetensi Emosi Pemimpin Mengikut Pengalaman Mentadbir di Sekolah Berkesan dan Sekolah Kurang Berkesan

Penyelidik telah membahagikan pengalaman mentadbir pemimpin sekolah dalam kajian ini kepada tiga kumpulan untuk tujuan analisis MANOVA iaitu kumpulan pentadbir yang berpengalaman kurang dari lima tahun; lima hingga sepuluh tahun; dan lebih dari sepuluh tahun. Hasil ujian Multivariate menunjukkan tidak terdapat perbezaan secara signifikan dalam skor min kompetensi emosi pemimpin berdasarkan pengalaman menjadi pentadbir sekolah. Hal ini terbukti apabila nilai Pillai trace yang diperoleh adalah sebanyak 0.018 (F = 1.089; p > 0.05) dan Roy's Largest Root pula sebanyak $0.015(\mathrm{~F}=1.78 ; \mathrm{p}>0.05)$. Secara amnya, ujian multivariate seperti yang ditunjukkan dalam Jadual 5 menunjukkan bahawa tidak terdapat perbezaan dari segi kompetensi emosi pemimpin secara keseluruhan $(\mathrm{F}=0.275$; $\mathrm{p}>0.05)$; kelompok kesedaran diri $(\mathrm{F}=$ 1.883; $\mathrm{p}>0.05)$; kesedaran sosial $(\mathrm{F}=0.242 ; \mathrm{p}>0.05)$; pengurusan diri $(\mathrm{F}=0.225 ; \mathrm{p}>0.05)$ dan pengurusan perhubungan $(\mathrm{F}=0.265 ; \mathrm{p}$ $>0.05)$. Sehubungan itu, keputusan ini menunjukkan tidak terdapat perbezaan yang signifikan dan positif dalam kompetensi emosi pemimpin berdasarkan pemboleh ubah pengalaman pentadbiran di sekolah berkesan dan sekolah kurang berkesan.

Seterusnya analisis lanjutan turut dilakukan bagi mengenal pasti perbezaan subskala-subskala kompetensi emosi pemimpin berdasarkan pengalaman responden menjadi pentadbir sekolah. Hasil analisis MANOVA (Jadual 6) mendapati tidak terdapat perbezaan skor min subskala kompetensi emosi pemimpin secara 
signifikan jika dirujuk kepada nilai Pillai trace yang diperoleh sebanyak 0.106 ( $\mathrm{F}=1.450 ; \mathrm{p}>0.05)$ dan Roy's Largerst Root sebanyak $0.086(\mathrm{~F}=2.231 ; \mathrm{p}>0.05)$. Hal ini dapat dilihat dalam Jadual 4 iaitu subskala-subskala kompetensi emosi iaitu kesedaran diri $(\mathrm{F}=2.45 ; \mathrm{p}>0.05)$; ketepatan penilaian kendiri $(\mathrm{F}=0.42 ; \mathrm{p}$ $>0.05)$; keyakinan diri $(\mathrm{F}=1.70 ; \mathrm{p}>0.05)$; empati $(\mathrm{F}=0.01 ; \mathrm{p}>$ $0.05)$; orientasi khidmat $(\mathrm{F}=1.11 ; \mathrm{p}>0.05)$; kesedaran organisasi $(\mathrm{F}=0.12 ; \mathrm{p}>0.05)$; pengawalan emosi diri $(\mathrm{F}=0.16 ; \mathrm{p}>0.05)$; orientasi pencapaian $(\mathrm{F}=2.33 ; \mathrm{p}>0.05)$; sikap optimis $(\mathrm{F}=0.66 ; \mathrm{p}$ $>0.05)$; ketelusan $(\mathrm{F}=0.91 ; \mathrm{p}>0.05)$; kebolehsuaian $(\mathrm{F}=0.59 ; \mathrm{p}$ $>0.05)$; inisiatif $(\mathrm{F}=0.48 ; \mathrm{p}>0.05)$; membangunkan orang lain $(\mathrm{F}$ $=1.04 ; \mathrm{p}>0.05)$; kepemimpinan berinspirasi $(\mathrm{F}=0.10 ; \mathrm{p}>0.05)$; pemangkin perubahan $(\mathrm{F}=0.49 ; \mathrm{p}>0.05)$; pengurusan konflik $(\mathrm{F}=$ $0.15 ; \mathrm{p}>0.05)$; pengaruh $(\mathrm{F}=1.22 ; \mathrm{p}>0.05)$; dan kerja kumpulan - kolaborasi $(\mathrm{F}=1.20 ; \mathrm{p}>0.05)$.

Jadual 5

Analisis MANOVA bagi Perbezaan Kompetensi Emosi Pemimpin Berdasarkan Pengalaman Mentadbir di Sekolah Berkesan dan Sekolah Kurang Berkesan

\begin{tabular}{lcccc}
\hline $\begin{array}{l}\text { Kelompok Kompetensi } \\
\text { Emosi Pemimpin }\end{array}$ & $\begin{array}{c}\text { Kurang dari } \\
\mathbf{5} \text { th. } \\
(\mathbf{n = 3 3 7}) \\
\text { Min }(\mathbf{S . P})\end{array}$ & $\begin{array}{c}\mathbf{5 - 1 0} \text { th. } \\
(\mathbf{n = 1 4 2})\end{array}$ & $\begin{array}{c}\text { Lebih dari }(\mathbf{S . P}) \\
\mathbf{1 0} \text { th. } \\
(\mathbf{n}=\mathbf{6})\end{array}$ & Nilai F \\
$\mathbf{M i n}(\mathbf{S . P})$ & \\
\hline $\begin{array}{l}\text { Kompetensi Emosi } \\
\text { Pemimpin }\end{array}$ & $3.79(0.37)$ & $3.82(0.38)$ & $3.81(0.31)$ & 0.275 \\
Kesedaran Diri & $3.80(0.32)$ & $3.86(0.32)$ & $3.79(0.31)$ & 1.883 \\
Kesedaran Sosial & $3.77(0.51)$ & $3.76(0.52)$ & $3.91(0.43)$ & 0.242 \\
Pengurusan Diri & $3.80(0.42)$ & $3.83(0.43)$ & $3.75(0.17)$ & 0.225 \\
Pengurusan Perhubungan & $3.80(0.41)$ & $3.83(0.42)$ & $3.79(0.36)$ & 0.265 \\
\hline
\end{tabular}

$* * \mathrm{p}<0.01 ; * \mathrm{p}<0.05$

Hal ini menunjukkan tidak terdapat perbezaan yang ketara dalam skor min berdasarkan bilangan tahun pengalaman menjadi pentadbir sekolah. Maka, kompetensi emosi pemimpin tidak dapat ditentukan berdasarkan pengalaman menjadi pentadbir di sesebuah sekolah sama ada di sekolah berkesan atan sekolah kurang berkesan. 
Jadual 6

Analisis MANOVA bagi Perbezaan Subskala Kompetensi Emosi Pemimpin berdasarkan Pengalaman Mentadbir

\begin{tabular}{|c|c|c|c|c|}
\hline $\begin{array}{c}\text { Subskala Kompetensi Emosi } \\
\text { Pemimpin }\end{array}$ & $\begin{array}{l}\text { Kurang } \\
\text { dari } 5 \text { th. } \\
(n=337)\end{array}$ & $\begin{array}{c}5-10 \\
\text { tahun } \\
(n=142)\end{array}$ & $\begin{array}{l}\text { Lebih dari } \\
10 \text { tahun } \\
\quad(n=6)\end{array}$ & Nilai $\mathbf{F}$ \\
\hline & $\operatorname{Min}(\mathbf{S . P})$ & $\operatorname{Min}(\mathbf{S . P})$ & $\operatorname{Min}(\mathbf{S . P})$ & \\
\hline Cesedaran Emosi Diri & $3.89(0.43)$ & $3.98(0.44)$ & $4.04(0.36)$ & 2.45 \\
\hline Ketepatan Penilaian Kendiri & $3.39(0.33)$ & $3.41(0.34)$ & $3.29(0.29)$ & 0.42 \\
\hline Keyakinan Diri & $4.13(0.47)$ & $4.21(0.44)$ & $4.04(0.33)$ & 1.70 \\
\hline impati & $4.03(0.52)$ & $4.02(0.49)$ & $4.04(0.43)$ & 0.01 \\
\hline rientasi Khidmat & $3.42(0.72)$ & $3.45(0.78)$ & $3.87(0.87)$ & 1.11 \\
\hline Kesedaran Organisasi & $3.85(0.63)$ & $3.81(0.68)$ & $3.83(0.64)$ & 0.12 \\
\hline Pengawalan Emosi Diri & $3.77(0.47)$ & $3.79(0.48)$ & $3.83(0.40)$ & 0.16 \\
\hline Orientasi Pencapaian & $3.90(0.54)$ & $3.91(0.59)$ & $3.41(0.20)$ & 2.33 \\
\hline Sikap Optimis & $4.10(0.55)$ & $4.13(0.52)$ & $3.87(0.20)$ & 0.66 \\
\hline Ketelusan & $4.05(0.50)$ & $4.11(0.47)$ & $4.20(0.55)$ & 0.91 \\
\hline Kebolehsuaian & $3.81(0.51)$ & $3.86(0.56)$ & $3.95(0.29)$ & 0.59 \\
\hline Inisiatif & $3.18(0.64)$ & $3.16(0.67)$ & $3.20(0.40)$ & 0.48 \\
\hline Membangunkan Orang Lain & $3.83(0.55)$ & $3.84(0.55)$ & $4.16(0.49)$ & 1.04 \\
\hline Kepemimpinan Berinspirasi & $3.99(0.60)$ & $4.01(0.58)$ & $3.95(0.43)$ & 0.10 \\
\hline Pemangkin Perubahan & $3.68(0.59)$ & $3.73(0.63)$ & $3.83(0.49)$ & 0.49 \\
\hline Pengurusan Konflik & $3.64(0.45)$ & $3.64(0.49)$ & $3.54(0.40)$ & 0.15 \\
\hline Pengaruh & $3.56(0.62)$ & $3.57(0.65)$ & $3.16(0.20)$ & 1.22 \\
\hline Kerja Kumpulan-kolaborasi & $4.11(0.50)$ & $4.19(0.43)$ & $4.08(0.49)$ & 1.20 \\
\hline
\end{tabular}

$* * \mathrm{p}<0.01 ; * \mathrm{p}<0.05$

\section{Perbezaan Kompetensi Emosi Pemimpin Berdasarkan Jantina}

Bagi menguji perbezaan faktor demografi responden di sekolah berkesan dan sekolah kurang berkesan, analisis Ujian-t telah digunakan dan dapatannya dipaparkan dalam Jadual 7. 
Jadual 7

Perbezaan Kompetensi Emosi Pemimpin Berdasarkan Jantina di Sekolah Berkesan dan Sekolah Kurang Berkesan

\begin{tabular}{|c|c|c|c|c|}
\hline $\begin{array}{l}\text { Kelompok Kompetensi } \\
\text { Emosi Pemimpin }\end{array}$ & $\begin{array}{c}\text { Lelaki } \\
(\mathrm{n}=138)\end{array}$ & $\begin{array}{l}\text { Perempuan } \\
(\mathbf{n}=347)\end{array}$ & $\begin{array}{l}\text { Perbezaan } \\
\text { Min }\end{array}$ & Nilai $t$ \\
\hline ) & Min (S.P) & $\operatorname{Min}(\mathbf{S . P})$ & & \\
\hline Kesedaran Diri & $3.85(0.35)$ & $3.81(0.31)$ & 0.04 & 1.42 \\
\hline Kesedaran Sosial & $3.85(0.47)$ & $3.73(0.52)$ & 0.12 & $2.37 * *$ \\
\hline Pengurusan Diri & $3.89(0.37)$ & $3.78(0.43)$ & 0.11 & $2.73 * *$ \\
\hline Pengurusan Perhubungan & $3.88(0.41)$ & $3.78(0.40)$ & 0.10 & $2.29 *$ \\
\hline $\begin{array}{l}\text { Kompetensi Emosi Pemimpin } \\
\text { Keseluruhan }\end{array}$ & $3.87(0.35)$ & $3.77(0.37)$ & 0.10 & $2.53 * *$ \\
\hline
\end{tabular}

$* * \mathrm{p}<0.01 ; * \mathrm{p}<0.05$

Dapatan daripada Jadual 7 menunjukkan bahawa secara keseluruhannya terdapat perbezaan skor min kompetensi emosi pemimpin secara signifikan dalam kalangan responden lelaki berbanding dengan responden perempuan $(\underline{\mathrm{t}}=2.53$; $\mathrm{p}<0.05)$. Dalam hal ini, perbezaan tersebut turut berlaku dalam kelompok kesedaran sosial $(\underline{t}=2.37 ; \mathrm{p}<0.05)$, kelompok pengurusan diri $(\underline{\mathrm{t}}=2.73 ; \mathrm{p}<0.05)$ dan kelompok pengurusan perhubungan $(\underline{\mathrm{t}}=$ $2.29 ; \mathrm{p}<0.05)$ tetapi tidak wujud perbezaan yang signifikan dalam kelompok kesedaran diri $(\underline{t}=1.42 ; \mathrm{p}>0.05)$.

Selain itu, perbezaan berdasarkan subskala-subskala kompetensi emosi pemimpin mengikut jantina dapat dilihat berdasarkan Jadual 8. Merujuk kepada Jadual 8, didapati wujud perbezaan skor min kompetensi emosi pemimpin secara signifikan berdasarkan jantina dalam kalangan responden lelaki berbanding responden perempuan dalam subskala ketepatan penilaian kendiri $(\underline{\mathrm{t}}=3.35 ; \mathrm{p}<0.05)$, subskala empati $(\underline{\mathrm{t}}=2.08 ; \mathrm{p}<0.05)$, subskala orientasi khidmat $(\mathrm{t}=2.35 ; \mathrm{p}<0.05)$, subskala orientasi pencapaian $(\mathrm{t}=3.43 ; \mathrm{p}<0.05)$, subskala kebolehsuaian $(\mathrm{t}=2.91 ; \mathrm{p}<0.05)$, subskala kepemimpinan berinspirasi $(\underline{t}=3.898 ; \mathrm{p}<0.05)$, subskala pemangkin perubahan $(\underline{\mathrm{t}}=2.19 ; \mathrm{p}<0.05)$ dan subskala pengaruh $(\underline{\mathrm{t}}$ $=2.25 ; \mathrm{p}<0.05)$. 
Manakala subskala-subskala kompetensi emosi yang didapati tidak wujud perbezaan skor min yang signifikan ialah subskala kesedaran emosi diri $(\underline{t}=0.36 ; p>0.05)$, keyakinan diri $(\underline{t}=0.95 ; \mathrm{p}>0.05)$, kesedaran organisasi $(\underline{\mathrm{t}}=1.30 ; \mathrm{p}>0.05)$, pengawalan emosi diri $(\underline{\mathrm{t}}$ $=1.47 ; \mathrm{p}>0.05)$, sikap optimis $(\underline{\mathrm{t}}=1.60 ; \mathrm{p}>0.05)$, ketelusan $(\underline{\mathrm{t}}=$ $1.45 ; \mathrm{p}>0.05)$, inisiatif $(\mathrm{t}=1.78 ; \mathrm{p}>0.05)$, membangunkan orang lain $(\underline{t}=1.11 ; p>0.05)$, pengurusan konflik $(\underline{t}=0.20 ; p>0.05)$, dan kerja kumpulan - kolaborasi $(\underline{\mathrm{t}}=0.26 ; \mathrm{p}>0.05)$.

\section{Jadual 8}

Perbezaan Subskala Kompetensi Emosi Pemimpin Berdasarkan Jantina di Sekolah Berkesan dan Sekolah Kurang Berkesan

\begin{tabular}{|c|c|c|c|c|}
\hline $\begin{array}{l}\text { Subskala Kompetensi Emosi } \\
\text { Pemimpin }\end{array}$ & $\begin{array}{l}\text { Lelaki } \\
(\mathrm{n}=138)\end{array}$ & $\begin{array}{l}\text { Perempuan } \\
(n=347)\end{array}$ & $\begin{array}{c}\text { Perbezaan } \\
\text { Min }\end{array}$ & $\begin{array}{c}\text { Nilai } \\
\underline{\mathbf{t}}\end{array}$ \\
\hline & $\operatorname{Min}(\mathbf{S . P})$ & $\operatorname{Min}(\mathbf{S . P})$ & & \\
\hline Kesedaran Emosi Diri & $3.90(0.43)$ & $3.92(0.43)$ & 0.01 & 0.36 \\
\hline Ketepatan Penilaian Kendiri & $3.48(0.34)$ & $3.36(0.32)$ & 0.12 & $3.35^{* *}$ \\
\hline Keyakinan Diri & $4.18(0.51)$ & $4.14(0.44)$ & 0.04 & 0.95 \\
\hline Empati & $4.11(0.49)$ & $4.00(0.51)$ & 0.10 & $2.08 *$ \\
\hline Orientasi Khidmat & $3.56(0.63)$ & $3.39(0.77)$ & 0.17 & $2.35^{* *}$ \\
\hline Kesedaran Organisasi & $3.90(0.62)$ & $3.81(0.65)$ & 0.08 & 1.20 \\
\hline Pengawalan Emosi Diri & $3.83(0.42)$ & $3.76(0.49)$ & 0.07 & 1.47 \\
\hline Orientasi Pencapaian & $4.03(0.53)$ & $3.84(0.55)$ & 0.19 & $3.43^{* *}$ \\
\hline Sikap Optimis & $4.17(0.50)$ & $4.08(0.55)$ & 0.08 & 1.60 \\
\hline Ketelusan & $4.12(0.45)$ & $4.05(0.51)$ & 0.07 & 1.45 \\
\hline Kebolehsuaian & $3.94(0.51)$ & $3.78(0.53)$ & 0.15 & $2.91 *$ \\
\hline Inisiatif & $3.26(0.61)$ & $3.14(0.66)$ & 0.11 & 1.78 \\
\hline Membangunkan Orang Lain & $3.88(0.53)$ & $3.82(0.55)$ & 0.06 & 1.11 \\
\hline Kepemimpinan Berinspirasi & $4.16(0.09)$ & $3.93(0.58)$ & 0.22 & $3.89 * *$ \\
\hline Pemangkin Perubahan & $3.79(0.58)$ & $3.66(0.60)$ & 0.13 & $2.19 *$ \\
\hline Pengurusan Konflik & $3.63(0.47)$ & $3.64(0.45)$ & 0.01 & 0.20 \\
\hline Pengaruh & $3.66(0.63)$ & $3.52(0.62)$ & 0.14 & $2.25^{*}$ \\
\hline Kerja Kumpulan-kolaborasi & $4.14(0.47)$ & $4.13(0.48)$ & 0.01 & 0.26 \\
\hline
\end{tabular}

$* * \mathrm{p}<0.05 ; * \mathrm{p}<0.05$ 


\section{Perbezaan Kompetensi Emosi Pemimpin Berdasarkan Sekolah Berkesan dan Sekolah Kurang Berkesan}

Kajian ini juga bertujuan untuk meneliti perbezaan kompetensi emosi pemimpin berdasarkan sekolah berkesan dan sekolah kurang berkesan. Perbezaan ini telah dikaji dengan menggunakan Ujian-t dan dapatannya ditunjukkan dalam Jadual 9.

Jadual 9

Perbezaan Kompetensi Emosi Pemimpin Berdasarkan Kategori Sekolah

\begin{tabular}{lcccc}
\hline $\begin{array}{c}\text { Kelompok } \\
\text { Kompetensi Emosi } \\
\text { Pemimpin }\end{array}$ & $\begin{array}{c}\text { Sekolah } \\
\text { Berkesan }\end{array}$ & $\begin{array}{c}\text { Sekolah Kurang } \\
\text { Berkesan } \\
(\mathbf{n}=\mathbf{2 3 3})\end{array}$ & $\begin{array}{c}\text { Perbezaan } \\
\text { Min }\end{array}$ & $\begin{array}{c}\text { Nilai } \\
\mathbf{t}\end{array}$ \\
& Min (S.P) & Min (S.P) & & \\
\hline Kesedaran Diri & $3.87(0.31)$ & $3.77(0.32)$ & 0.10 & $3.467^{* * *}$ \\
Kesedaran Sosial & $3.85(0.48)$ & $3.69(0.53)$ & 0.16 & $3.551^{* *}$ \\
Pengurusan Diri & $3.88(0.39)$ & $3.74(0.43)$ & 0.13 & $3.601^{* *}$ \\
Peng. Perhubungan & $3.90(0.37)$ & $3.72(0.43)$ & 0.18 & $4.953^{* *}$ \\
K. Emosi Pemimpin & $3.88(0.34)$ & $3.73(0.39)$ & 0.14 & $4.367 * *$ \\
\hline
\end{tabular}

$* * \mathrm{p}<0.01 ; * \mathrm{p}<0.05$

Jadual 9 menunjukkan bahawa secara keseluruhannya terdapat perbezaan skor min kompetensi emosi dalam kalangan pemimpin sekolah berkesan dan sekolah kurang berkesan secara signifikan $(\underline{\mathrm{t}}=4.367 ; \mathrm{p}<0.05)$. Dalam hubungan itu, kelompok-kelompok kompetensi emosi pemimpin juga turut menunjukkan perbezaan secara signifikan iaitu kelompok kesedaran diri $(\underline{\mathrm{t}}=3.467$; $\mathrm{p}<$ 0.05), kelompok kesedaran sosial $(\underline{t}=3.551 ; \mathrm{p}<0.05)$, kelompok pengurusan diri $(\underline{\mathrm{t}}=3.601 ; \mathrm{p}<0.05)$ dan kelompok pengurusan perhubungan $(\underline{\mathrm{t}}=4.953 ; \mathrm{p}<0.05)$, antara sekolah berkesan berbanding dengan sekolah kurang berkesan.

Rumusannya, skor min kompetensi emosi pemimpin dan kelompok kompetensi emosi pemimpin di sekolah berkesan adalah lebih tinggi berbanding skor min di sekolah kurang berkesan secara signifikan. 
Dapatan analisis lanjutan terhadap subskala-subskala kompetensi emosi pemimpin di sekolah berkesan dan sekolah kurang berkesan juga dipaparkan dalam Jadual 10. Berdasarkan dapatan daripada Jadual 10 tersebut menunjukkan subskala-subskla kompetensi emosi pemimpin mempunyai perbezaan skor min secara signifikan dalam kalangan pemimpin di sekolah berkesan dan sekolah kurang berkesan kecuali subskala ketepatan penilaian kendiri $(\underline{\mathrm{t}}=0.727$; $\mathrm{p}>$ 0.05). Dalam hubungan ini, subskala-subskala yang turut menunjukkan perbezaan dalam skor min ialah kesedaran emosi diri $(\underline{\mathrm{t}}=3.855 ; \mathrm{p}<0.05)$, keyakinan diri $(\mathrm{t}=3.156 ; \mathrm{p}<0.05)$, empati $(\underline{\mathrm{t}}$ $=2.612 ; \mathrm{p}<0.05)$, orientasi khidmat $(\mathrm{t}=2.257 ; \mathrm{p}<0.05)$, kesedaran organisasi $(\underline{t}=3.790 ; \mathrm{p}<0.05)$, pengawalan emosi diri $(\mathrm{t}=3.380 ; \mathrm{p}$ $<0.05)$, orientasi pencapaian.

Jadual 10

Perbezaan Subskala Kompetensi Emosi Pemimpin Berdasarkan Kategori Sekolah Berkesan dan Sekolah Kurang Berkesan

\begin{tabular}{|lcccc}
\hline $\begin{array}{c}\text { Subskala Kompetensi } \\
\text { Emosi Pemimpin }\end{array}$ & $\begin{array}{c}\text { Sekolah } \\
\text { berkesan }\end{array}$ & $\begin{array}{c}\text { Sekolah } \\
\text { Kurang } \\
\text { berkesan }\end{array}$ & $\begin{array}{c}\text { Perbezaan } \\
\text { Min }\end{array}$ & Nilai \\
\hline & (n = 233) & (n = 252) & & \\
\hline Kesedaran Emosi Diri & $3.99(0.43)$ & $3.84(0.42)$ & 0.15 & $3.85^{* *}$ \\
\hline K. Penilaian Kendiri & $3.41(0.32)$ & $3.39(0.34)$ & 0.02 & 0.72 \\
\hline Keyakinan Diri & $4.22(0.46)$ & $4.09(0.45)$ & 0.13 & $3.15^{* *}$ \\
\hline Empati & $4.09(0.48)$ & $3.97(0.53)$ & 0.12 & $2.61^{* *}$ \\
\hline Krientasi Khidmat & $3.52(0.71)$ & $3.36(0.76)$ & 0.16 & $2.25^{*}$ \\
\hline Pesedaran Organisasi & $3.95(0.64)$ & $3.73(0.64)$ & 0.22 & $3.79^{* *}$ \\
\hline Orientasi Pencapaian & $3.85(0.50)$ & $3.71(0.43)$ & 0.14 & $3.38^{* *}$ \\
Sikap Optimis & $3.97(0.52)$ & $3.83(0.57)$ & 0.14 & $2.91^{* *}$ \\
\hline Ketelusan & $4.17(0.47)$ & $4.04(0.59)$ & 0.13 & $2.62^{* *}$ \\
\hline Kebolehsuaian & $4.15(0.46)$ & $4.00(0.51)$ & 0.15 & $3.39^{* *}$ \\
\hline Inisiatif & $3.88(0.53)$ & $3.78(0.51)$ & 0.10 & $1.94^{*}$ \\
\hline & $3.26(0.61)$ & $3.10(0.67)$ & 0.16 & $2.61^{* *}$ \\
\hline
\end{tabular}




\begin{tabular}{lcccc}
\hline \multicolumn{1}{c}{$\begin{array}{c}\text { Subskala Kompetensi } \\
\text { Emosi Pemimpin }\end{array}$} & $\begin{array}{c}\text { Sekolah } \\
\text { berkesan }\end{array}$ & $\begin{array}{c}\text { Sekolah } \\
\text { Kurang } \\
\text { berkesan }\end{array}$ & $\begin{array}{c}\text { Perbezaan } \\
\text { Min }\end{array}$ & Nilai \\
& Min (S.P) & Min (S.P) & & \\
\hline Membangunkan Orang & $3.95(0.49)$ & $3.74(0.57)$ & 0.21 & $4.23^{* *}$ \\
Lain & & & & \\
Kepemimpinan Berinspirasi & $4.08(0.51)$ & $3.91(0.64)$ & 0.17 & $3.17^{* *}$ \\
Pemangkin Perubahan & $3.82(0.58)$ & $3.58(0.60)$ & 0.24 & $4.47^{* *}$ \\
Pengurusan Konflik & $3.70(0.45)$ & $3.58(0.46)$ & 0.12 & $2.66^{* *}$ \\
Pengaruh & $3.67(0.59)$ & $3.45(0.64)$ & 0.22 & $3.76^{* *}$ \\
Kerja Kumpulan-kolaborasi & $4.21(0.46)$ & $4.06(0.49)$ & 0.15 & $3.33^{* *}$ \\
\hline
\end{tabular}

$* * p<0.01 ; * p<0.05$

$(\underline{\mathrm{t}}=2.910 ; \mathrm{p}<0.05)$, sikap optimis $(\underline{\mathrm{t}}=2.628 ; \mathrm{p}<0.05)$, ketelusan $(\underline{t}=3.394 ; \mathrm{p}<0.05)$, kebolehsuaian $(\underline{t}=1.945 ; \mathrm{p}<0.05)$, inisiatif $(\underline{\mathrm{t}}=2.613 ; \mathrm{p}<0.05)$, membangunkan orang lain $(\underline{\mathrm{t}}=4.237 ; \mathrm{p}<$ $0.05)$, kepemimpinan berinspirasi $(\underline{\mathrm{t}}=3.177 ; \mathrm{p}<0.05)$, pemangkin perubahan $(\mathrm{t}=4.475 ; \mathrm{p}<0.05)$, pengurusan konflik $(\mathrm{t}=2.666 ; \mathrm{p}<$ $0.05)$, pengaruh $(\underline{t}=3.762 ; \mathrm{p}<0.05)$, dan kerja kumpulan-kolaborasi $(\mathrm{t}=3.332 ; \mathrm{p}<0.05)$.

\section{Perbezaan Kepemimpinan Sekolah di Sekolah Berkesan dan Sekolah Kurang Berkesan}

Seterusnya kajian ini juga bertujuan meneliti perbezaan kepemimpinan dalam kalangan pemimpin di sekolah berkesan dan sekolah kurang berkesan. Perbezaan skor min kepemimpinan iaitu tingkah laku kepemimpinan Transformasional antara pemimpin di sekolah berkesan dan sekolah kurang berkesan telah dianalisis dengan menggunakan Ujian t dan dipaparkan dalam Jadual 11.

Dapatan dari Jadual 11, menunjukkan bahawa skor min kepemimpinan Transformasional yang diperoleh sekolah berkesan adalah lebih tinggi berbanding skor min yang diperoleh sekolah kurang berkesan. Justeru, perbezaan ini apabila diuji dengan Ujian-t, nilai $\underline{\mathrm{t}}$ yang signifikan diperoleh $(\underline{\mathrm{t}}=3.623 ; \mathrm{p}<0.05)$ bagi kepemimpinan Transformasional. Seterusnya dimensi dalam kepemimpinan Transformasional juga menunjukkan perbezaan 
skor min pada aras yang signifikan antara pemimpin di sekolah berkesan dan sekolah kurang berkesan iaitu dimensi karismatik (atribut) $(\underline{\mathrm{t}}=3.058 ; \mathrm{p}<0.05)$, dimensi karismatik (tingkah laku) $(\underline{\mathrm{t}}=2.443 ; \mathrm{p}<0.05)$, dimensi mencetus motivasi $(\underline{\mathrm{t}}=2.384 ; \mathrm{p}<$ $0.05)$, dimensi merangsang intelektual $(\underline{t}=3.905 ; \mathrm{p}<0.05)$ kecuali dimensi pertimbangan individu $(\underline{\mathrm{t}}=1.824 ; \mathrm{p}>0.05)$. Keputusan ini menjelaskan bahawa amalan kepemimpinan Transformasional seperti karismatik (atribut dan tingkah laku), mencetus motivasi, merangsang intelektual lebih tinggi di sekolah berkesan kecuali bagi dimensi pertimbangan individu.

Jadual 1.11

Perbezaan Kepemimpinan Transformasional Berdasarkan Kategori Sekolah Berkesan dan Sekolah Kurang Berkesan

Dimensi Kepemimpinan Transformasional
SKB Perbezaan Nilai

Min

$$
\underline{\mathbf{t}}
$$

\begin{tabular}{lcccc}
\multicolumn{1}{c}{ Transformasional } & & Min & t \\
& $(\mathbf{n}=\mathbf{2 3 3})$ & $(\mathbf{n}=\mathbf{2 5 2})$ & & $\underline{ }$ \\
\hline Kepemimpinan & Min (S.P) & Min (S.P) & & \\
\hline $\begin{array}{l}\text { Transformasional } \\
\text { Karismatik (atribut) }\end{array}$ & $3.95(0.43)$ & $3.81(0.50)$ & 0.14 & $3.26^{* *}$ \\
\hline Karismatik (tingkah laku) & $3.80(0.55)$ & $3.64(0.60)$ & 0.16 & $3.05^{* *}$ \\
\hline Mencetus Motivasi & $4.14(0.51)$ & $4.02(0.63)$ & 0.12 & $2.38^{* *}$ \\
\hline Merangsang Intelektual & $3.98(0.51)$ & $3.78(0.61)$ & 0.20 & $3.90^{* *}$ \\
\hline Pertimbangan Individu & $3.85(0.54)$ & $3.76(0.57)$ & 0.09 & 1.82 \\
\hline
\end{tabular}

$* \mathrm{p}<0.01 ; * \mathrm{p}<0.05$

Berdasarkan Jadual 12, dapatan dalam aspek kepemimpinan Transaksi menunjukkan skor min kepemimpinan Transaksi di sekolah kurang berkesan lebih tinggi dari sekolah berkesan. Apabila diuji dengan ujian-t didapati tidak wujud perbezaan yang signifikan $(\underline{t}=2.45 ; \mathrm{p}>0.05)$ bagi kepemimpinan Transaksi. Pola yang sama juga dapat dilihat bagi dimensi pengurusan pengecualian (aktif) ( $\underline{\mathrm{t}}$ $=0.74 ; \mathrm{p}>0.05)$. Namun begitu, dimensi-dimensi kepemimpinan Transaksi yang lain menunjukkan perbezaan skor min pada aras yang signifikan antara pemimpin di sekolah berkesan dan sekolah kurang berkesan iaitu bagi dimensi ganjaran luar jangka $(\underline{t}=1.63$ ' 
$\mathrm{p}<0.05)$, pengurusan pengecualian (pasif) $(\underline{\mathrm{t}}=3.03$; $\mathrm{p}<0.05)$, dan kepemimpinan laissez-faire $(\underline{\mathrm{t}}=3.59$; $\mathrm{p}<0.05)$. Dapatan ini menunjukkan tidak terdapat perbezaan yang signifikan dari segi kepemimpinan laissez-faire dalam kalangan pemimpin sekolah berkesan dan sekolah kurang berkesan.

Jadual 12

Perbezaan Kepemimpinan Transaksi dan Kepemimpinan LaissezFaire Berdasarkan Kategori Sekolah Berkesan dan Sekolah Kurang Berkesan

\begin{tabular}{lcccc}
\hline $\begin{array}{c}\text { Dimensi Kepemimpinan } \\
\text { Transaksi }\end{array}$ & SB & SKB & $\begin{array}{c}\text { Perbezaan } \\
\text { Min }\end{array}$ & Nilai \\
& $(\mathbf{n = 2 3 3 )}$ & $(\mathbf{n = 2 5 2 )}$ & & $\underline{\mathbf{t}}$ \\
& Min (S.P) & Min (S.P) & & \\
\hline Kepemimpinan Transaksi & $3.56(0.53)$ & $3.67(0.49)$ & 0.11 & 2.45 \\
Ganjaran Luar Jangka & $4.12(0.60)$ & $4.20(0.37)$ & 0.08 & $1.63^{* *}$ \\
Peng. Pengecualian (Aktif) & $4.00(0.61)$ & $4.04(0.60)$ & 0.04 & 0.74 \\
Peng. Pengecualian (Pasif) & $2.55(0.75)$ & $2.78(0.89)$ & 0.22 & $3.03^{* *}$ \\
Kepem. Laissez- Faire & $2.47(0.77)$ & $2.76(0.96)$ & 0.28 & $3.59^{* *}$ \\
\hline
\end{tabular}

$* * \mathrm{p}<0.01 ; * \mathrm{p}<0.05$

\section{RUMUSAN DAN PERBINCANGAN}

\section{Perbezaan Kompetensi Emosi Pemimpin dari Aspek Pemboleh ubah Demografi di Sekolah Berkesan dan Sekolah Kurang Berkesan}

Secara umumnya, perbezaan-perbezaan di dalam kompetensi emosi pemimpin yang berkaitan dengan pemboleh ubah demografi iaitu, umur, jantina dan pengalaman pentadbiran di dalam kajian ini dapat dilihat dari segi tahap kompetensi emosi pemimpin. Hasil kajian mendapati wujud perbezaan yang signifikan dari segi umur terhadap kelompok-kelompok kompetensi emosi pemimpin iaitu kelompok kesedaran diri, kelompok kesedaran sosial, kelompok pengurusan diri dan kelompok pengurusan perhubungan dalam kalangan pemimpin di sekolah berkesan dan sekolah kurang berkesan. Berkaitan dengan 
perbezaan ini, hasil analisis menunjukkan bahawa tahap umur dalam kalangan pemimpin di sekolah berkesan dan sekolah kurang berkesan mempengaruhi tahap kompetensi emosi mereka.

Seterusnya, hasil kajian ini tidak dapat membuktikan perbezaan dari segi pengalaman pentadbiran berdasarkan kelompokkelompok kompetensi emosi pemimpin di sekolah berkesan dan sekolah kurang berkesan. Kajian ini turut mendapati perbezaan yang signifikan di dalam kompetensi emosi pemimpin berdasarkan jantina di sekolah berkesan dan sekolah kurang berkesan. Berdasarkan teori yang dikemukakan oleh Bar-On (1997), terdapat banyak persamaan dalam kompetensi emosi antara lelaki dan perempuan atau tidak wujud perbezaan antara jantina berkaitan dengan kecerdasan emosi. Berkaitan dengan jantina juga, hasil kajian ini menunjukkan bahawa pemimpin lelaki mempunyai kompetensi emosi yang lebih tinggi daripada pemimpin perempuan di sekolah berkesan dan sekolah kurang berkesan. Dapatan ini selari dengan kajian yang dijalankan oleh Hopkins (2005), Rivera (2003), dan Mandell dan Pherwani, (2003) di mana responden lelaki memperoleh skor kompetensi emosi yang lebih tinggi dari responden perempuan di dalam subskala kesedaran emosi diri, ketepatan penilaian kendiri, pengawalan emosi diri, keyakinan, prihatin, kebolehsuaian, orientasi khidmat, pemangkin perubahan dan kesetiaan terhadap organisasi.

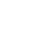

\section{Perbezaan Kompetensi Emosi Pemimpin dan Kepemimpinan di Sekolah Berkesan dan Sekolah Kurang Berkesan}

Perbezaan di antara sekolah berkesan dan sekolah kurang berkesan di dalam kajian ini adalah dilihat berdasarkan kepada kompetensi emosi pemimpin dan kepemimpinan Transformasional dan kepemimpinan Laissez-Faire dalam kalangan pemimpin di dua kategori sekolah tersebut. Secara lebih terpeinci, hasil kajian ini mendapati bahawa wujud perbezaan dalam kompetensi emosi pemimpin secara keseluruhan. Perbezaan yang signifikan juga wujud dalam kelompok kesedaran diri, kelompok kesedaran sosial, kelompok pengurusan diri dan kelompok pengurusan perhubungan kalangan pemimpin sekolah berkesan dan sekolah kurang berkesan.

Kajian ini juga menunjukkan tidak terdapat perbezaan yang signifikan dalam kepemimpinan Transaksi dalam kalangan pemimpin di sekolah berkesan dan sekolah kurang berkesan. Kepemimpinan Transaksi lebih bersifat reaktif dan tidak cenderung kepada hubungan yang bersifat personel atau bersifat empati 
dalam memenuhi keperluan subordinat (Barling \& Kelloway, 2000). Berkaitan dengan perbezaan ini, hasil analisis menunjukkan bahawa tahap kompetensi emosi dalam kalangan pemimpin sekolah berkesan adalah lebih tinggi berbanding dengan pemimpin di sekolah kurang berkesan. Hasil kajian oleh Boyatzis (1982), Goleman (2001), Sitarenios (2000), Derman (1999), Bachman, (2000), Berr, Church, dan Waclawski (2000), Rozell, (2006), dan Rode, Money, Arthaud-Day, Near, Baldwin, Rubin \& Bommer, (2007) yang turut mendapati bahawa kompetensi emosi pemimpin dalam organisasi yang berkesan adalah lebih tinggi berbanding dengan organisasi yang kurang berkesan.

Selain dari itu, hasil kajian ini juga membuktikan bahawa subskala-subskala kompetensi emosi pemimpin sekolah berkesan adalah juga lebih tinggi dari pemimpin di sekolah kurang berkesan. Antaranya ialah subskala kesedaran emosi diri, keyakinan diri, empati, orientasi khidmat, kesedaran organisasi, pengawalan emosi diri, orientasi pencapaian, sikap optimis, ketelusan, kebolehsuaian, inisiatif, membangunkan orang lain, kepemimpinan berinspirasi, pemangkin perubahan, pengurusan konflik, pengaruh dan kerja kumpulan-kolaborasi. Kajian ini juga turut mendapati perbezaan yang signifikan dari segi tahap kepemimpinan Transformasional dalam kalangan pemimpin sekolah berkesan dan sekolah kurang berkesan.

Berkaitan dengan kepemimpinan Transformasional juga, hasil kajian menunjukkan bahawa tahap kepemimpinan Transformasional dalam kalangan pemimpin sekolah berkesan adalah lebih tinggi berbanding dengan pemimpin di sekolah kurang berkesan. Dapatan ini selaras dengan kajian-kajian oleh Silins (1993, 1994), Charles dan Karr-Kidwell, (1995), dan Fergerson dan Nochelski, (1996) yang mendapati wujud perbezaan antara organisasi berkesan dan organisasi kurang berkesan adalah disebabkan amalan kepemimpinan Transformasional.

Secara keseluruhannya, penjelasan yang boleh dikaitkan dengan perbezaan dapatan dalam aspek kompetensi emosi pemimpin dan kepemimpinan Transformasional ialah persekitaran yang wujud dalam konteks organisasi sekolah berkenaan yang berkemungkinan mempengaruhi perbezaan dapatan kajian (Bozeman, 1989). Faktorfaktor seperti ekonomi dan politik (Bozeman, 1989), pembiayaan dan bentuk-bentuk pengawalan sosial (Rainey, 1983), dan aktiviti pengurusan (Fottler, 1981; Perry \& Porter, 1982) berkemungkinan mendatangkan perbezaan dalam konteks kepemimpinan dan pengurusan di sekolah berkesan dan sekolah kurang berkesan. 


\section{KESIMPULAN}

Secara keseluruhannya, hasil kajian menunjukkan kompetensi emosi memainkan peranan penting dalam meningkatkan tahap kepemimpinan transfromasional dalam kalangan pemimpin di sekolah berkesan dan juga sekolah kurang berkesan. Sehubungan itu, kelompok-kelompok kesedaran diri, kesedaran sosial, pengurusan diri dan pengurusan perhubungan harus diambil kira sebagai elemen penting dalam merancang program-program yang akan meningkatkan tahap kemahiran dan pengukuhan kepemimpinan .

Kajian ini juga memerihalkan tentang subskala-subskala kompetensi emosi yang berpengaruh dan berkesan sebagai sumber pengukuhan dalam kepemimpinan. Di sekolah berkesan, hasil kajian mendapati subskala kebolehsuaian dan pengaruh merupakan subskala utama yang mempengaruhi pengukuhan kepemimpinan Transformasional. Pengetahuan subskala kompetensi emosi yang berpengaruh ini memungkinkan peningkatan dan pengekalan kepemimpinan yang lebih tinggi dan berkesan. Namun begitu, dalam masa yang sama, subskala-subskala kompetensi lain perlulah juga dipertingkatkan. Antaranya ialah subskala kesedaran emosi, empati, kesedaran organisasi, orientasi pencapaian, sikap optimis, inisiatif, kepemimpinan berinspirasi, pemangkin perubahan, pengurusan konflik dan kerja kumpulan-kolaborasi. Hasil kajian menunjukkan subskala-subskala kompetensi emosi tersebut juga perlu dipertingkatkan di sekolah kurang berkesan. Aspek-aspek lain yang perlu diberi penekanan ialah aspek demografi iaitu umur dan jantina pemimpin sekolah. Hal ini kerana dapatan kajian menunjukkan kedua-dua faktor tersebut berbeza dalam tahap kompetensi emosi pemimpin sama ada di sekolah berkesan atau sekolah kurang berkesan. Aspek kompetensi emosi dan tingkah laku kepemimpinan perlu diberi perhatian seirus kerana ia merupakan penentu kepada kerancakan kualiti pengajaran dan pembelajaran di sekolah seterusnya dapat meningkatkan lagi jumlah sekolah-sekolah berkesan di Malaysia.

\section{RUJUKAN}

Bass, B. M. (1990). Bass \& stogdill's handbook of leadership: Theory, research \& managerial applications. New York: Free Press. 
Bass, B. M. \& Avolio, B. J. (1994). Improving organizational effectiveness through transformational leadership. Thousand Oaks, CA: Sage.

Bass, B., \& Avolio, B. (2000). MLQ: Multifactor leadership questionnaire (2nd ed.). Technical Report. Redwood City, CA: Mind Garden.

Bass, B. M. (1985). Leadership and performance beyond expectations. New York: Free Press.

Bar-On, R. (1997). Emotional quotient inventory: Technical manual. Toronto: Multi Health Systems.

Bachman, J.(2000). Emotional intelligence in the collection of debt. International Journal of Selection and Assessment, 8(3), 176182.

Barling, J. Slater, F., \& Kelloway, E. K. (2000). Transformational leadership and emotional intelligence: An exploratory study. The Leadership and Organizational Development Journal, 21, 157-161.

Berr, S., Church, A., \& Waclawski, A. (2000). The right relationship is everything: Linking personality performance to management behaviors. Human Resource Development Quarterly, 11 (2), $133-157$.

Bennis, W. \& Nanus, B. (1985). Leaders: The strategies for taking charge. New York: Harper \& Row.

Blasé, J., \& Blasé, J. R. (1994). Empowering teachers: What succesful principal do. Thousand Oaks: Corwin Press.

Blasé, J., \& Blasé, J. R. (1994). Empowering teachers: What succesful principal do. Thousand Oaks: Corwin Press.

Blasé, J., Blasé, J., Anderson, J., \& Dungan, S. (1995). Democratic principals in action. Thousand Oaks: Crown Press.

Burns, J. M. (1978). Leadership. New York, NY: Harper \& Row.

Boyatzis, R. E. (2001). Developing Emotional Intelligence. In C. Cherniss, R. Boyatzis \& M. Elias (Eds.), Developments in emotional intelligence (pp. 121-154). San Francisco: JosseyBass.

Boyatzis, R. E. (1982). The component manager, model for effective performance. New York: John Wiley \& Sons.

Bozeman, B. (1989). All organization are public: Bridging public and private organizational theories. London: Josey-Bass.

Button, B. (2003). A study examining the use of transformational leadership practice for teacher development. Dissertation Master of Science (Education), University of WisconsinStout: Menomonie, WI. 
Chastukhina, $\mathrm{N}$ (2002). On the role of emotional intelligence in organizations, Proceedings of the Organisational Systems Research Association Conference, St Louis. Retrieved from http://www.osra.org/2002/contents.html

Charles, G. S., \& Karr-Kidwell, P. J. (1995). Effective principal, effective schools: Arriving at site based decision-making with succesful principals and teacher participation. ERIC Document Reproduction Service No. ED 382564.

Chou Lin, H. (1999). A study of principals leadership style and school effectiveness in selected secondary schools in New Jersey. EdD Dissertation: Seton Hall University, New Jersey.

Coakes, S. J., \& Steed, L. G. (2003). SPSS: Analysis without anguish, version 11.0 for windows. New South Wales: John Willey \& Sons.

Derman, L. (1999). The relationship between the emotional intelligence of family-member managers and business success in family businesses. Dissertation Abstracts International, 60-05B, 2397.

Dyer, K. M. (2001). Relational leadership. The School Administrator, 58(10), 28-31. Retrieved from http://www.aasa.org/publications /sa/2001_11/dyer.htm

Feldman, D. C. (1999). The handbook of emotional intelligent leadership. Fall Church, VA: Leadership Performance Solutions.

Ferguson, J. M., \& Nochelski, P. (1996). The power of letting go. American School Board Journal, 83(4), 37-39.

Fottler, M. (1981). Is management really generic? Academy of Management Review, 6, 1-11.

Forsyth, D. R. (2000). Social comparison and influence in groups. In J. Suls \& L. Wheeler (Eds.), Handbook of social comparison: Theory and research (pp. 81-103).

George, J. M. (2000). Emotions and Leadership: The role of emotional intelligence. Human Relations, 53(8), 1027-1054.

George, J.M. \& Bettenhausen, K. (1990). Understanding prosocial behavior, sales performance, and turnover: A group level analysis in a service context. Journal of Applied Psychology, 75, 698-709.

Goldring, E. B., \& Rallis, S. F. (1993). Principals of dynamic schools: Taking charge of change. Newbury Park: Corwin Press. 
Goleman, D. (2001). An EI-based theory of performance. In C. Cherniss \& D. Goleman (Eds.), The emotionally intelligent workplace. San Francisco: Jossey- Bass.

Goleman, D. (1998). What makes a leader? Harvard Business Review, pp. 93-102.

Gorard, S. (2001). Quantitative methods in educational research: The role of numbers made easy: London: Continuum.

Haskin, K. (1995). A process of learning: The principal role in participatory management. ERIC Document Reproduction Service No. ED 385949.

Herman. (1991) Cross-cultural self report: Why we should and when we shouldn't. Paper presented in Symposium, Selfreport measurement issues in microorganizational research, Academy of Management Annual Meeting, Atlanta, GA.

Hopkins, M. M. (2005). The impact of gender, emotional intelligence competencies, and styles on leadership success (Unpublished doctorial dissertation). Case Western Reserve University: United State of America.

Johnson, B., \& Christensen, L. (2005). Educational research: Quantitative, qualitative, and mixed approaches (2nd ed). Boston, MA: Pearson Education.

Lashway, L. (1997). Multidimensional school leadership. Bloomington. In Phi Delta Kappa Educational Foundation.

Lees, A. \& Barnard, D. (1999). Highly effective headteachers: An analysis of a sample of diagnostic data from the Leadership Programme for Serving Headteachers. Report prepared for Hay/McBer research group. Retrieved from http://www.dfee. gov.uk/ teachingreforms/mcber

Leithwood, K. A. (1993). Contributions of transformational leadership to school restructuring. Paper presented at the Convention of the University Council for Educational Administration, Houston, TX.

Mayer, J. D. \& Salovey, P. (1997). What is emotional intelligence. In P. Salovey, \& D. Sluyter, Emotional development and emotional intelligence: Educational implications (pp. 3-34). New York: Basicbooks.

Mandell, B., \& Pherwani, S. (2003). Relationship between emotional intelligence and transformational leadership style: A gender comparison. Journal of Business and Psychology, 17(3), 387404. 
Nanus, B. (1992). Visionary leadership: Creating a compelling sense of direction for your organization. San Francisco: Jossey-Bass.

Noyes, R. (2002). Emotional intelligence and leadership. Leadership International. Available Online: www. Leadership International. Com.

Perry, J., \& Porter, L. (1982). Factors affecting the context for motivation in public organization. Academy of Management Review, 7, 89-98.

Rainey, H. G. (1983). Public agencies and private firms: Incentives, goals and individuals roles. Administration and Society, 15(2), 207-242.

Rievera, B. (2003). An across contexts comparison of emotional competencies. (Education dissertation). Case Western Reserved University, Cleveland, Ohio.

Rozell, E. J., Pettijohn, C. E., \& Parker, S. R. (2006). Emotional intelligence and dispositional affectivity as predictors of performance in salespeople. Journal of Marketing Theory and Practice, 14 (2), 113 - 124.

Rode, J. C., Monney, C. H., Arthaud-Day, M. L., Near, J. P., Baldwin, T. T., Rubin, R. S., \& Bommer, W. H. (2007). Emotional intelligence and individual performance: Evidence of direct and moderated effects. Journal of Organizational Behaviour.

Sergiovanni, T. J. (1996). Leadership basic for principals and their staff. The Educational Forum, 60 (3), 267-270.

Sillins, H. C. (1993). The relationship between school leaders and school improvement outcome. Paper presented at the Annual Meeting of the American Educational Research Association, Atlanta, GA.

Sillins, H. C. (1994). The relationship between transformational leadership and transactional leadership and school improvement outcomes. School Effectiveness and School Improvement, 5(3), 272-298.

Sitarenios, G. (2000). Emotional Intelligence in the prediction of placement success in the company "Business Incentives". Toronto, Canada: Multi-Health Systems.

Stogdill, R. M. (1974). Handbook of leadership. New York: The Free Press.

Stone, P. (1992). Transformational leadership in principals: An analysis of the multifactor leadership questionnaire. Professional Leadership Development Monograph Series, 2(1). ERIC Document Reproduction Service No. 355613. 
Weisinger, H. (1998). Emotional intelligence at work: The untapped edge for success. San Francisco, CA: Jossey-Bass.

Yukl, G. (2002). Leadership in organizations (4th ed.) Upper Saddle River, NJ: Prentice Hall.

Yukl, G. \& Van Fleet, D.D. (1992). Theory and research on leadership in organizations. In M.D. Dunnette and L.M. Hough (Eds.), Handbook of Industrial and Organizational Psychology, 3(PP. 147-97). Palo Alto, CA: Consulting Psychologists Press. 


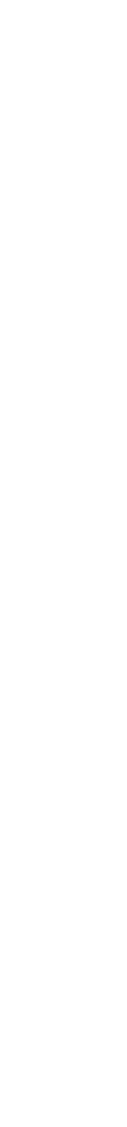

